\title{
2 Policies and practices against labour movement in the late Russian Empire
}

\author{
Volodymyr Kulikov and Irina Shilnikova
}

\section{Introduction}

On 3 October 1913 the chief of Saint Petersburg secret police submitted a report to the Department of Police about the political "spirit" in the city in which he sincerely acknowledged that any preventive measures against the labour movement, such as repression of trade unions, are useless. "The current labour movement is a kind of psychosis", he explained. "In some cases, the repressions may even turn to be harmful, because liquidation [of the workers' organisations] can only accelerate the explosion of the strike movement". ${ }^{1}$ This note epitomises the ultimate result of tsarist's labour policy: it could not seize the labour movement despite increasing the power of its repressive apparatus. This chapter investigates why practices of the government and employers against the labour movement in the late Russian Empire turned to be inefficient.

The industrial boom in the Russian Empire, starting from the 1880s, brought economic growth and modernisation. At the same time, like other rapidly industrialised countries, it was accompanied by fierce labour conflicts. Employees demanded higher wages, fewer working hours, better living conditions and more respect. Employers were upset by the instability caused by labour migration, as well as by the low level of productivity and lack of discipline on behalf of their workers. Labour conflicts often burst into violence on both sides, which embroiled the third side - the government. Other actors, such as the church, radical socialists, journalists and scholars, were also involved, but it was mostly the industrialists and the government that determined the balance of power and the outcome of the labour conflicts.

Although the history of the labour movement in the Russian Empire has been researched in detail by historians, they paid less attention to the repressive policies and practices of the employers and state authorities; so, no comprehensive study has been written on the topic. Contemporaries studied the repressions against the labour movement in the context of elaborating factory legislations and tried to find the best solution for the so-called labour problem. ${ }^{2}$

Soviet historians approached the topic from the perspective of the class conflict. ${ }^{3}$ They contributed to our knowledge about the repressive policy of the government, mostly presenting it in the context of the general repressive policy of tsarism against its citizens. ${ }^{4}$ In the same period, especially in the 1950s to the 


\section{Volodymyr Kulikov and Irina Shilnikova}

1960s, papers by several American and British scholars explained how the tsarist administration and the employers managed labour protests in Russia. ${ }^{5}$

After the collapse of the Soviet Union, interest in labour history significantly declined in Eastern Europe. However, a group of Russian scholars organised an extensive research project to study labour conflicts in the Russian Empire at the end of the nineteenth and in the early twentieth century. They collected materials about thousands of conflicts from 112 archives of the former Soviet Union and published it as a multivolume series entitled Labour Movement in Russia. 1895 February of 1917. Chronicle. ${ }^{6}$

Using the materials of these publications, a group of historians created a relation database of all known cases of labour conflicts in the Russian Empire from 1895 until 1904 (7,769 records; about 4,757 strikes). ${ }^{7}$ The results of the analysis of this database were presented in several publications. ${ }^{8}$ This study also relies on the database, focusing on the empirical evidence on practices against the strikes. It is a combination of a quantitative analysis of practices against the labour movement with a qualitative analysis of anti-strike and anti-union policy.

This chapter describes the evolution of labour policy and practices against strikers adopted by the industrialists and the government in the late Russian Empire. The first part on policy presents an overview of the legislation about strikes, explores how the attitude of governments and industrialists towards the labour movement transformed in time. The second part describes the emergence and development of the repressive forces. The third part about practices is based on the results of a quantitative analysis of punitive actions against strikes. Overall, the chapter explains the strategy developed by industrialists and state authorities to prevent the labour movement and traces the evolvement of this strategy in the period from the 1870s until 1917.

To understand approaches against labour movement, national and regional chronicles of the labour conflicts, legislative materials and reflections regarding labour conflicts published by the contemporaries - industrialists, politicians and scholars in social sciences - were analysed. These sources were supplemented by some archival documents providing relevant case materials to illustrate the practices and to present the situation from the perspective of the strikers.

\section{Striking movement in the Russian Empire: a brief overview}

Strikes in the 1870s, such as that at the Nevsky Thread Manufacturing Co. in 1870 , at Krenholm Manufacturing Co. in 1872, and at the Iuzovka Ironworks in 1875 , marked the beginning of a new era in the economic and social development of Russia. From that time on strikes became the "new normality" in Russia.

Figure 2.1 presents the dynamics of strikes in the Russian Empire in the period between 1870 and 1894. During these decades, the labour movement was relatively moderate, with a few resonant conflicts and a low level of involvement of revolutionary organisations. The two peaks in 1878-79 and 1887 were because of a series of massive protests at the textile factories in Saint Petersburg, Moscow, and a few other centres of the textile industry. 


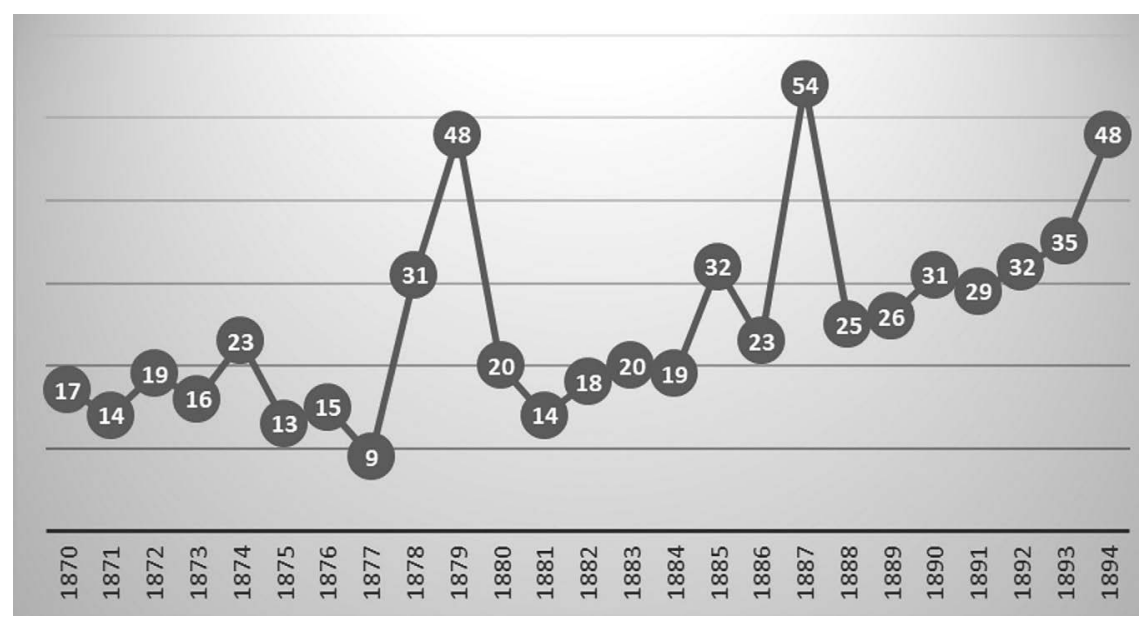

Figure 2.1 Number of strikes in the Russian Empire from 1870 to 1894

Sources: Anna M. Pankratova, Rabochee dvizhenie v Rossii v XIX veke: Sbornik dokumentov $i$ materialov. T. 2: 1861-1884. Ch. 1. 1861-1874 (Moscow: Gospolitizdat, 1950), 607-18.; Ibid. Vol. 2. Part 2: 1875-1884, 644-676; Moscow, 1950; Ibid. Vol. 3. Part. 1: 1885-1889, 771-802; Ibid. Vol. 3. Part. 2: 1885-1894, 620-645. Moscow, 1952.

From the mid-1890s, the labour movement transformed: strikes were no longer spontaneous but organised. The labour movement became a mass phenomenon and quickly politicalised. This was partly because of objective reasons, such as the emergence of large modern enterprises and the increasing number of professional workers, but also because of some questionable political decisions, such as the total ban of trade unions (in force until 1905). The revolutionary organisations saw the situation as an opportunity to establish themselves as the acting side in labour conflicts. They helped workers to grasp and defend their interests. On the other hand, they often encouraged workers to strike and exacerbate the conflict even if it would have been possible to avoid it through negotiations with the employers.

Daniel Brower has described a typical scenario of strike violence at the turn of the nineteenth century. ${ }^{9}$ A series of grievances triggered the conflict. That was followed by a work stoppage and the gathering of a crowd, "unorganised but with individuals formulating complaints". The administration of the enterprise refused to negotiate until the workers got back to their working places. If there were any representatives of the authorities (a factory inspector, police force), they demanded that the strikers stopped "rioting". They explained that strikers first had to surrender unconditionally and return to their jobs, and their grievances would have been examined only afterward. They would often arrest the delegates. Workers began to attack administrative buildings and company stores. If they had got access to alcohol, it catalysed the violence. The destructive phase usually lasted 
a day or two. Then military troops arrived, dispersed the crowd, beat the strikers and arrested as many of them as possible. The next phase was an investigation run by the state authorities. Many of the most active strikers - the "instigators" - were imprisoned, and a few dozen of them were deported to their own villages.

The most likely consequences for strikers are vividly presented in a propaganda poster distributed by the authorities (Figure 2.2). This poster published in Moscow in 1906 displays six images demonstrating "numerous disasters caused by unjustified strikes which are harmful to all people, but primarily to the strikers, who do not wish to work honestly". The text emphasised that strikes are "no godly activity" instead, it "brings terrible distress and utter destruction". The first image showing the battle with the military troops is followed by the image of wounded workers in the hospital. The next one depicts the arrest of the strikers. In the following picture, the worker is selling his boots because he does not receive a salary anymore and run out of money. Then he is fired and finally finds himself on Khitrovka, a square in the centre of Moscow which used to be a job market for unskilled labour. This place was infamous for its unsanitary conditions, crime and overall misery.

The number of strikes in the period between 1895 and 1917, as presented in Figure 2.3, hundreds, sometimes thousands per year, indicates that the governmental propaganda must have been inefficient. In the early twentieth century, the peaks were designated by the General Strike of 1903 in Southern Russia, the Russian Revolution of 1905, and the years following the Lena massacre of 1912.

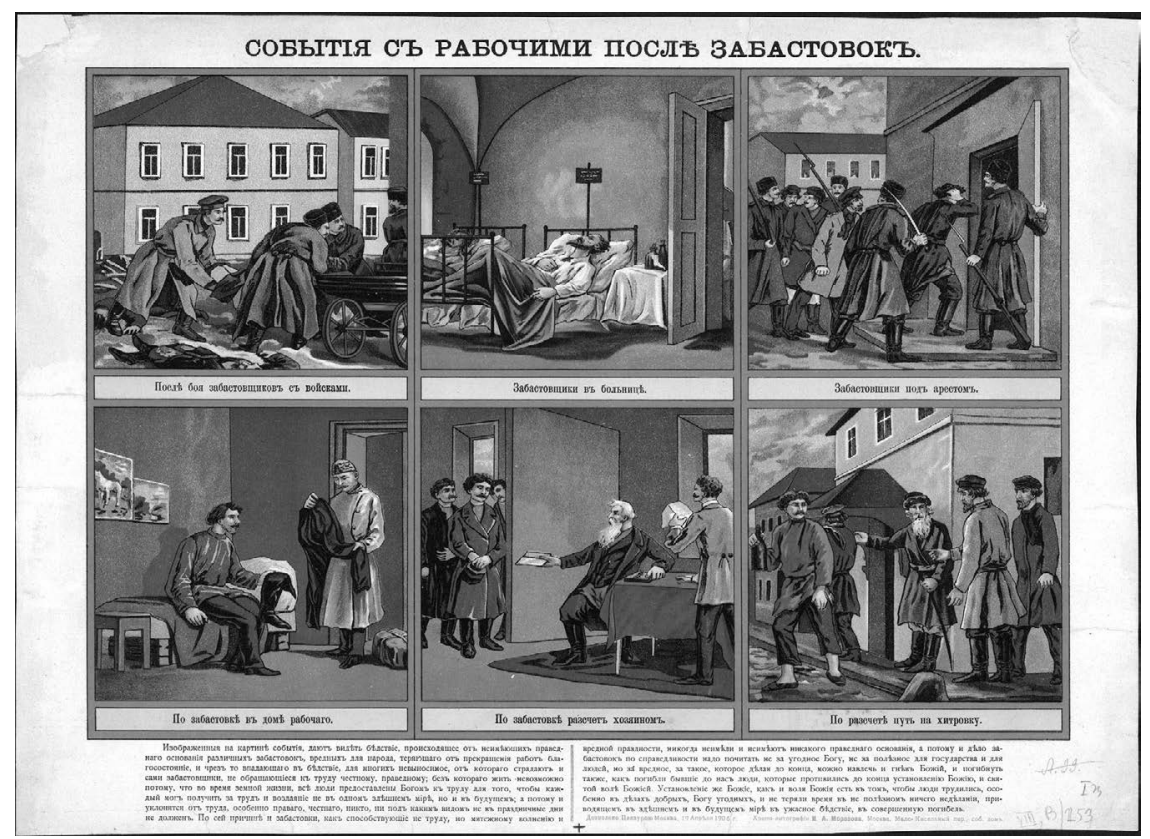

Figure 2.2 What happens to workers after the strike

Sources: "Sobytiia s rabochimi posle zabastovki," (Moscow: Tipografiia I. A. Morozova, 1906). 


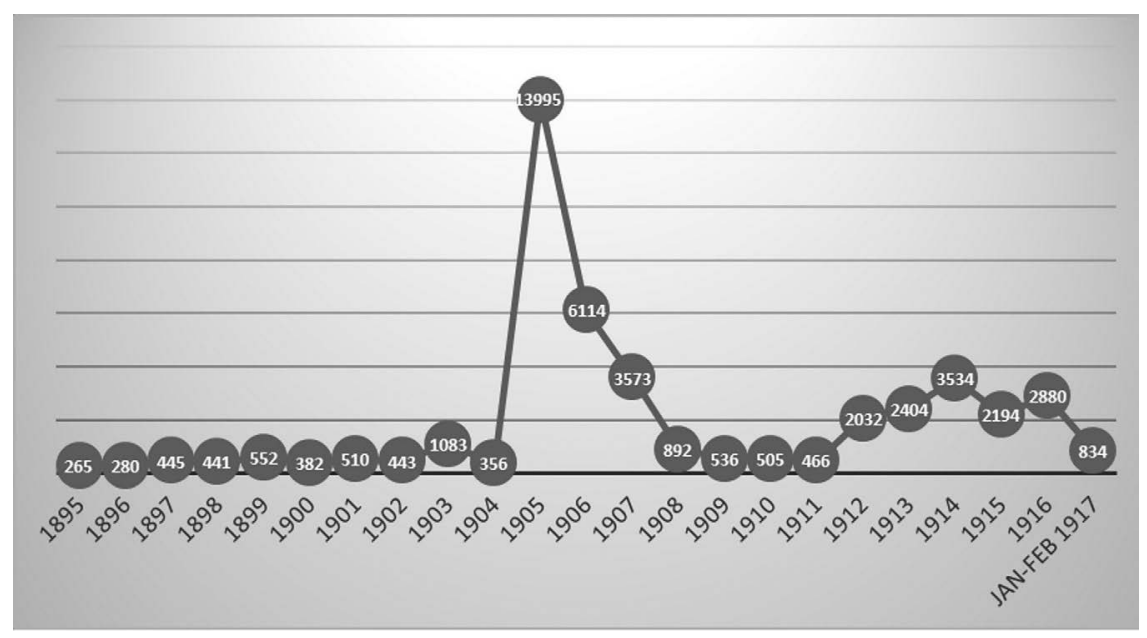

Figure 2.3 Number of strikes in the Russian Empire from 1895 to early $1917^{11}$

The number of strikes remained high during the First World War. There was only a short period at the beginning of the war when patriotism was skyrocketing and workers refrained from protesting. ${ }^{10}$ Workers were ready to strike again by the autumn of 1915 because of the poor performance of the Russian army on the front and a significant decrease in their living conditions.

\section{The rationale of tsarist labour policy}

The development of the labour movement induced the government and the industrialists to develop a policy towards this phenomenon. According to the government's perception, the "patriarchal" attitude of the employers and a strict hierarchy determined the relationship between industrialists and workers. As the Minister of Finances, Sergei Witte described it in a secret circular issued on the 5 December 1895,

The patriarchy [between master and worker] expresses itself in many cases in the concern of the factory owner for the needs of the worker and employees in his factory, in his solicitude for the preservation of harmony and agreement, in the simplicity and justice of their mutual relations. ${ }^{12}$

In the eyes of the government, the employer was a benevolent master who took care of the moral and material well-being of his workers. The state saw its own role as an independent agency standing above the interplay of conflicting and private interests and above partisanship.

Strike had no place in such a hierarchical model of labour relations. It was not perceived as an argument between the competing sides but as the "misbehaviour" of the subordinate side, which undermined the principle of the public order. 
Theoretically, workers were offered some mechanisms to seek justice against a misbehaving employer. They were supposed to appeal to a representative of the state (who was above the employer in the hierarchy) and who could punish the violator. In practice, the enormous power of industrialists and the limited rights of workers led to many cases of power abuse. ${ }^{13}$

Moreover, the system proved to be inefficient in those cases when the violations of workers' rights were reported with the expectation to restore justice. This convinced workers that the only way to attract the attention of officials was to strike. In theory, both employers and employees had equal rights to receive state protection. In practice, the government always took the side of the employers and cooperated with them in repressing the strikers. Courts examined all violent conflicts, but relatively few were those cases when the administrators were punished for provoking a strike. For the government, the social order always received priority over justice. ${ }^{14}$

The government interpreted strikes not as a private affair but as a matter of public concern; this is the reason why the public authorities were to be informed and involved immediately in any (even potential) mass labour conflict. As Minister Sergei Witte explained, "the government cannot accept the situation that workers achieve what they wanted even if employers expressed a desire to satisfy such demands". ${ }^{15}$ The government's approach to managing strikes was based on what economists call "collective action problem". The willingness of a company to put an end to the strike as soon as possible empowered the workers; consequently, it could harm collective entrepreneurial interests. The government presented itself as a body whose role was to balance private and collective interests for the common good and intended to regulate these through labour legislation.

In 1882, the government established a factory inspection as an institution to facilitate the implementation of factory legislation, to collect statistical information about workers and to act as a mediator between employees and employers. Factory inspectors were kept busy, preventing strikes until the end of the Russian Empire. However, many of their representatives admitted that, though this institution was very efficient in the late nineteenth and early twentieth century, after 1905 their peace-making effect and ability to negotiate significantly faded. ${ }^{16}$

Strikes and unions were unlawful in the Russian Empire up to 1905. Those who dared to strike risked facing "the knout, jail, or exile". ${ }^{17}$ The first law about strikes appeared in 1845 as an amendment to the Penal Code. It was elaborated with more details and slightly changed in 1874 and 1886 . According to the law, strikers were to be imprisoned for a period of two to four months, while "instigators" risked spending four to eight months in prison. In the case of aggravating circumstances, such as damaging factory property or forcing other workers to cease work, the punishment was doubled. ${ }^{18}$ The government cancelled the criminal penalty for strikes only in 1905, and even then, with some special conditions.

The state interpreted any labour conflict as a threat to public order, even if the conflict evolved for economic reasons; this is why strikes fell inside the scope of criminal law and not of civil law. Since strikes meant a challenge to the autocratic regime, they were seen as a matter of public concern. ${ }^{19}$ No wonder that in many official papers, strikes were called "disorder", "unrests", or "riots" (besporiadki, bunty). 
In practice, however, it was difficult to follow the law strictly. Sometimes, strikes involved hundreds and thousands of participants, so the police could not criminalise each of them. The solution was to criminalise the group of the most active strikers, and the rest received some forms of administrative punishment. The most popular among the latter was to expel strikers to remote provinces or to the villages where they were registered. ${ }^{20}$ Such actions were regulated by a number of secret circulars issued by the Ministry of Interior and the Ministry of Finance. The most infamous one was the circular signed on the 12 August 1897, in which the Minister of Interior Ivan Goremykin strongly recommended that the governors united the efforts of all officials and the regional police forces to stop the "disturbances among the workers". The minister demanded that the local police monitor carefully the factories and workers' houses. As a preemptive measure, he encouraged the police to arrest those individuals who were suspected to be political agitators. The circular reminded the officials that any unauthorised gathering of workers was strictly forbidden, and the organisers of such meetings were to be arrested immediately. The minister ordered his subordinates to do their best to put an end to any strike quickly and peacefully. Those workers who refused to cooperate were to be arrested and exiled.

Still, the minister acknowledged that "it is not always possible to conduct prosecution due to the lack of evidence of any crime", so his recommendation was to apply "administrative punishment on a mass scale". ${ }^{21}$ The recommendation to punish workers who were not formally recognised guilty was unlawful; this is why the circular was disseminated secretly. Instructions like this encouraged repression rather than reconciliation and easily led to the abuse of power.

By 1905 the labour movement became so intense that it was impossible to tackle it with only repressive actions, which demonstrated the failure of the previous tsarist labour policy. The government had to liberalise the legislation. In April 1905, it cancelled the circular from the 12 August 1897. In October 1905, in the context of the revolution, the emperor issued a manifesto which granted the freedom of conscience, speech, assembly and association. The "Temporary regulations on unions and societies" issued on 4 March 1906 legalised the formation of trade unions and educational societies and, at the same time, clarified the "rules" for the workers' assemblies.

Trade unions functioned actively in 1905 and 1906, even despite the significant limitations. ${ }^{22}$ Efforts by the unions were mostly channelled into the struggle for improving the workers' material conditions. Nevertheless even these limited activities irritated the government, which intensified the efforts to repress the unions from 1907. The slightest reason was enough to close down the existing trade unions and to obstruct the registration of new ones. The government permitted a limited restoration of the workers' assembly after the Lena massacre in April 1912, but trade unions were considered suspicious until the time when tsarism collapsed. ${ }^{23}$

Though those aspects of factory law which fall outside the repressive elements in labour legislation are beyond the scope of this paper, the fact itself that Russia developed its factory legislation in the period between 1882 and 1912 has a significance for the topic. More than ten acts were issued in this period regulating child and woman work, the number of daily working hours and penalties and 
introducing social securities. These acts improved the working conditions considerably but did not lead to a decrease in the intensity of the labour movement.

\section{The labour policy of the industrialists}

Most industrialists agreed with the government in this respect and also saw any conflict between the employer and employee as a deviation from normality, which should be hushed up by all means. Both the traditional theory of paternalism and social Darwinism, that time the two most popular social ideologies among industrialists, considered disputes and strikes as an anomaly. In terms of the paternalistic approach, strikes were a sign of a supreme ingratitude, a fight against corporate benevolence. For social Darwinism, a strike was a break in the social order: the presence of wealth and poverty was seen as a part of the "normal" order reflecting the differences among people in their abilities and efforts.

The picture of Russian workers created by industrialist was very persistent, presenting them as being backward and lazy, but amendable to the influence of socialist propaganda. Because of this image, the employers generally preferred repression to negotiation. Nikolai Avdakov, an influential member (and later chairman) of the Association of Southern Coal and Steel Producers, concluded his report in 1893 on how to secure workforce supply for coal-mining enterprises with the following words: "A rioting spirit has appeared among the miners due to the high wages and their drunkenness. Therefore, we need more police forces to maintain decorum and order among the workers". ${ }^{24}$ Industrialists like Avdakov looked at the strikes as a zero-sum game, so power was the key to determine which side gains and which loses.

The tactic of increasing repressive forces worked on the local level but proved to be ineffective in preventing the labour movement in general. Thus, industrialists relied on the combination of stick and carrot policy. Welfare work was a recurrent topic during the discussions at the meetings of the regional associations of industrialists starting from the 1880s. From that time on, enterprises invested heavily in social infrastructure and improved the working and living conditions of their employees..$^{25}$ However, the expanding enterprises and the rapidly increasing number of workers often negated the efforts of the enterprises to improve the quality of life of its staff. Although the working and living conditions were steadily improving during the period between 1870 and 1914, many contemporaries described them even in the 1910s as inhuman and intolerable. Modern technologies and luxurious offices of the new technocracy often coexisted with primitive forms of economic coercion, debilitating physical labour and extreme poverty. ${ }^{26}$

The changing economic situation, the broadening and strengthening of the working class and the intensifying labour movement pushed the industrialists towards making their labour policy more flexible. Their position concerning the legalisation of worker's organisations gradually changed. Even the most conservative industrialists had to accept that the total ban of such institutions was counterproductive. The conservative chief executive of the Dnieper Company, the 
owner of the largest metallurgy plant in the Russian Empire, said in April 1905: "The current labour law and the law about strikes do not correspond anymore to the reality. If the law is permanently violated and the state has no power to prevent this, the law should be adjusted [to the reality]". ${ }^{27}$ Therefore, the emperor's decision to legalise the workers' organisation in 1905 did not meet any significant opposition from the side of the industrialists.

The intensification of the labour movement also inspirited the industrialists to unite and coordinate their efforts in the face of a new threat. They started to establish their own organisations aimed to give mutual support in the struggle against strikes. These organisations were usually operating at a regional scale. The Association of Southern Coal and Steel Producers, founded in 1874, coordinated the policy and practices against the labour movement in the Dnepr-Donbas region. In Saint Petersburg, the industrialists established the St. Petersburg Society for Assistance to the Improvement and Development of Factory Industry in 1897. The society collected and analysed information about all strikes that happened in the region to adjust its labour policy. The members established a special fund for their mutual assistance in cases of lengthy strikes, and they also coordinated their actions against strikers. The Moscow entrepreneurs created the Society of Factory Owners of Moscow Industrial Region in 1907. The funding chart of this society contained articles about mutual support, including financial, consulting and legislative means. By 1908 there were 18 such societies in the Russian Empire, mostly in large cities such as Saint Petersburg, Moscow, Ekaterinoslav and Kharkov. ${ }^{28}$

Many Soviet historians presented the relationship between the entrepreneurs and the state as having been cooperative, aimed to repress workers: when violent conflicts arose, the industrialists and the government combined their efforts to put it down ${ }^{29}$. However, behind the scenes, there were many conflicting interests not only between the business and the state but also within these two groups.

The business community was characterised by local differences. Industrialists of the Moscow region retained their more traditional, patriarchal practices, firmly opposing any worker organisation. They often stated that workers are a "dark poorly-literate crowd", which can easily be manipulated by revolutionists. ${ }^{30}$ In contrast, their peers in Saint Petersburg and the Dnepr-Donbas regions gradually shifted from oppressive towards rationalising labour policy. ${ }^{31}$ However, there were disagreements from time to time, even within the regional groups. For example, the members of the eighteenth congress of the Association of Southern Coal and Steel Producers in December 1893 had a very heated discussion about how to tackle the labour movement. A participant of the congress, Vladimir Vagner, suggested that every ten to 15 workers elected a so-called desiatskikh who would represent the interests of their group and communicate it to the authorities. However, most of the industrialists present at the congress rejected the idea arguing that the workers were "backward" and not ready for such practices. Instead, they insisted on asking the government to strengthen the police forces in the region. ${ }^{32}$

From the perspective of the industrialists, the strengthening of the police control had several disadvantages, the most disturbing one being the police meddling in the concerns of business. The government justified police interference based 
on the principle of conflict prevention. To promote industrial development, the Ministry of Finance backed the interests of the industrialists. The position of the Ministry of the Interior was shaped by other influencers, such as the landowning nobility. ${ }^{33}$ This ministry prioritised public order and the prevention of violent labour conflicts and conducted several investigations which demonstrated that many conflicts were caused by the poor working conditions and by industrialists violating the law. Thus, the ministry developed the following strategy: 1 to urge employers to improve the working conditions; 2 to prevent violent conflict through their undercover network and preventive arrests; and 3 to suppress workers' "disorders" promptly and firmly in case the preventive measures failed. ${ }^{34}$

Despite the previously mentioned tensions, all stakeholders agreed regarding the necessity of powerful police forces at their disposal. Police could be used either to repress the labour movement or to strengthen the employers' position during the negotiations in time of labour conflicts.

\section{Repressive forces}

The first strikes in the 1870s broke out spontaneously, and the reaction of the police was rather slow. Therefore, the industrialists had to rely on their own solutions to suppress the "rioters". The enterprises often applied the principle of divide et impera: they used a group of loyal workers to repress the rioting ones. ${ }^{35}$ Factory workers could be turned against miners, skilled workers against non-skilled ones and foreign employees (who were always better paid) against the locals. Sources present some cases when companies or the local authorities armed peasants from the surrounding villages to repress the striking miners. ${ }^{36}$

The government found it suspicious when unofficial military groups were used, especially if it was done by foreign-managed enterprises, so it decided to enforce police presence in the factories. The government granted free access to the police into the factories, and police could inspect and arrest workers who fell under suspicion any time in the presence of a factory manager. ${ }^{37}$ Because of the immediate interventions of the police and military forces on behalf of management, many wage conflicts tended to be characterised by the government as political.

However, the government could not provide sufficient police forces to supervise every enterprise. The presence of police was especially weak in small company towns scattered in a large geographical area. To strengthen the controlling forces, the enterprises supported the police service on their premises by establishing factory police or paying the local police department for increasing their presence at the factory. By the end of the 1890 s, there were officially 572 factory policemen in Russia, mostly in the Central Industrial and South Industrial regions. Their service was costly. For example, the Aleksandrovsk SouthRussian Plant of Briansk Society spent 15,900 roubles annually to support 60 policemen at the turn of the century while, in 1902, they spent 37,284 roubles on medical service and 17,282 on schools. ${ }^{38}$ Still, the officials acknowledged that these forces were inadequate as well as distributed unequally, mostly concentrated in the large settlements. 
This solution entailed an ethical problem as well: policemen receiving their pay checks from industrialists saw labour conflict through the eyes of their employer. The leadership of the police forces even acknowledged that in such cases, the police did not serve justice but acted as a servant of the entrepreneurs. ${ }^{39}$ On the 1 February 1898, the government issued a new law enforcing police presence in the factories. The costs were divided between the taxpayers and the industrialists: the government paid the salaries while the enterprises covered the expenses of the accommodation and the utilities of the newly enforced police body.

From the 1880 s, the priority tasks of the secret police in Imperial Russia, the so-called Okhranka (Otdeleniye po Okhraneniyu Obshchestvennoy Bezopasnosti $i$ Poryadka), were broadened with tackling the labour movement. This included investigating and preventing unauthorised meetings or demonstrations such as worker strikes. While the ordinary policeman, the gendarmes, were focused on formal investigations, the Okhranka operated through informers, spies and undercover agents. ${ }^{40}$ From 1898 on, the Okhranka monitored and accumulated information about the strikes and workers' organisations all over the country. They established a system of surveillance targeting both illegal and legal worker organisations, with special focus on trade unions. A circular issued by the Okhranka explained that some unions "drew themselves towards extremely harmful antigovernment activities and thus forced us to repress them by all possible means". ${ }^{41}$

Sources offer evidence that police used mercenary agents and involved street hooligans to provoke violence. A worker called Zakharkin recalled that during the 1905 revolution, the police "instigated hooligans" in looting pubs and to have a hand in Jewish pogroms. He referred to the example of Iuzovka, where there "was [the gang of] Alyoshka Sibiryak and two hundred men with him. Of course, they were connected to the police". ${ }^{42}$

Perhaps the most well-known enterprise of the Okhranka was establishing a spoiler work organisation under the control of the police at the turn of the century. Following the old principle, "if you cannot beat them, join them", the chief of the Moscow Secret Police, colonel Sergey Zubatov offered to create a legal workers' organisation under police supervision to defend their economic interests. He argued that it would allow the workers to seize the initiative from the socialist organisations and thus to have primacy in seeking for governmental support. However, his primary motivation was to have a certain degree of control over the workers' activities. ${ }^{43}$ The police chief of Moscow, Dmitri Trepov, and the governor-general of Moscow, Grand Duke Sergei Alexandrovich, both supported the proposal of Zubatov. The minister of interior hesitated first but finally gave the green light to the project. Between 1901 and 1903, Zubatov established workers' organisations in several large cities in the European part of Russia. Zubatov's initiative faced severe opposition on behalf of the employers and in some government circles. The minister of finances, Sergei Witte, believed that the project initiated by Zubatov and Trepov "catalyzes disturbance among the workers", de facto "replaced revolutionary propaganda" and aimed "to overthrow capitalism". ${ }^{44}$ The minister of the interior also had concerns about the project: he assumed that these legalised workers' organisations could easily be transformed into illegal and even 
oppositional organisations. He was afraid that workers were gaining experience in organising themselves, which they could later utilise in demonstrations, strikes and revolution. ${ }^{45}$ The general strike of 1903 in Southern Russia was the last straw, and after that, the minister stopped the project.

In those cases, when the police forces could not stop mass violence, the government sent army troops. However, it was not infrequent that the conflict had already been over for some days by the time the army arrived. Thus, industrialists asked the government to station troops near the large enterprises in those regions where enterprises clustered. The minister of war was not very enthusiastic to comply with this request since, as he explained, stationing troops in the industrial regions to "pacify riots" obstructed proper military training. ${ }^{46}$ Furthermore, sending military troops to repress labour violence often resulted in massacres, which attracted unwanted public attention and criticism, and ultimately contributed to the radicalisation of workers. The minister of the interior, Vyacheslav Pleve, believed that extreme mass violence threw workers to the arms of the revolutionists. Following the massacre in Zlatoust, Ufa Province, in March 1903, when local military troops killed 45 workers, he told the minister of war in private that he wished the troops would not use "such deadly bullets". ${ }^{77}$

Therefore, both the government and industrialists preferred to rely on the intervention of the Cossacks, the light cavalry force of a historically privileged social group famous for its pro-monarchist views. Cossacks acted violently and were very efficient in dispersing crowds, but without mass killings since they used non-lethal weapons such as nagaika - a thick, tightly twisted whip. However, they were inefficient against the passive resistance of workers.

\section{Practices against strikers}

Based on their rich experience in suppressing "unrests" on the factories and mines, the authorities and industrialists developed a toolbox of practices against strikers. The most popular solutions included dismissals, calling for police or military units, followed by arrests and exile, lockouts, strikebreaking and blacklisting. The following section discusses which of these were preferred by the employers and the government, and how often they were applied.

The relational database entitled "Chronicle of the labour movement" contains data about 4,757 strikes, which took place in all regions of the Russian Empire between 1895 and $1904 .^{48}$ The database allows tracing the popularity of specific repressive methods and their dynamics in this period. It also provides evidence on the efficiency of these methods to put an end to the conflict. Built on the basis of that database, Table 2.1 demonstrates that police or military troops interfered with 14 per cent of the strikes. The number of cases of police/military intrusion fluctuated from year to year, with 70 occasions on average in the period of 1895 to 1899 and 72 from 1900 through 1904. However, because of the increasing absolute number of strikes, this still means a slight relative decrease in the share of conflicts with police/military involvement, from 18 per cent to 13 per cent. The gradual decline continued after 1904 as well. 
Table 2.1 Repressive practices against strikers in Russian industry in the period from 1895 to 1904

\begin{tabular}{|c|c|c|c|c|c|c|}
\hline \multirow[t]{2}{*}{ Year } & \multirow{2}{*}{$\begin{array}{l}\text { Number of } \\
\text { strikes }\end{array}$} & \multicolumn{5}{|c|}{ The reaction of the authorities } \\
\hline & & $\begin{array}{l}\text { Police or } \\
\text { military } \\
\text { intervention }\end{array}$ & Trials & Arrests & Banishment & $\begin{array}{l}\text { Lockout or } \\
\text { dismissal of a } \\
\text { group of workers }\end{array}$ \\
\hline 1895 & 265 & $16 \%$ & $5 \%$ & $9 \%$ & $2 \%$ & $11 \%$ \\
\hline 1896 & 280 & $20 \%$ & $3 \%$ & $18 \%$ & $6 \%$ & $11 \%$ \\
\hline 1897 & 445 & $18 \%$ & $4 \%$ & $15 \%$ & $6 \%$ & $14 \%$ \\
\hline 1898 & 441 & $18 \%$ & $3 \%$ & $13 \%$ & $4 \%$ & $12 \%$ \\
\hline 1899 & 552 & $17 \%$ & $2 \%$ & $15 \%$ & $5 \%$ & $10 \%$ \\
\hline 1900 & 382 & $15 \%$ & $3 \%$ & $12 \%$ & $3 \%$ & $12 \%$ \\
\hline 1901 & 510 & $11 \%$ & $1 \%$ & $11 \%$ & $4 \%$ & $10 \%$ \\
\hline 1902 & 443 & $16 \%$ & $1 \%$ & $10 \%$ & $1 \%$ & $13 \%$ \\
\hline 1903 & 1083 & $13 \%$ & $1 \%$ & $8 \%$ & $1 \%$ & $10 \%$ \\
\hline 1904 & 356 & $1 \%$ & $\mathrm{n} / \mathrm{a}$ & $6 \%$ & $2 \%$ & $7 \%$ \\
\hline AVG & 476 & $14 \%$ & $2 \%$ & $12 \%$ & $3 \%$ & $11 \%$ \\
\hline
\end{tabular}

There were various factors behind this phenomenon. First, though the labour moment intensified, the authorities could not develop the police forces at the same pace. Therefore, they had to be more selective about where to interfere. In the late nineteenth century, military forces were often used just to intimidate the potential rioters, as a preventive measure against labour violence. From the early twentieth century, however, the government could not afford this anymore; they sent troops only in cases of actual mass violence.

At the same time, the effect of the violent oppression of strikers has also changed. Instead of pacifying the situation, it often aroused the indignation of workers also in the neighbouring enterprises and resulted in a powerful strike movement for the sake of solidarity. The Lena massacre of 1912, which triggered an immense wave of strikes and protests in the entire empire, is a textbook example for such a process. As Michael Melancon pointed out, the Lena massacre and other similar violent episodes "delivered successive blows that cracked and then shattered the last fragile remnants of Russia's post-1905 consensus" and as a result "workers, peasants and much of the educated society turned their backs on tsarism and capitalism". ${ }^{49}$

In the period of the First World War, the share of "political" among all strikes were around 24 per cent in the first two years, slightly declined in 1916, then sharply increased in early 1917 to 51 per cent. The difficult situation at the front and loosening discipline on the factories and mines made the authorities put more pressure on workers. However, violence against the strikers also led to public outcry and solidarity strikes, such as the series of strikes in the Central Industrial Region of Russia in August 1915. In early June 1915, workers of the Big Linen Manufactory in Kostroma demanded an increase in housing expense reimbursement. The administration did not give them a clear answer, so the workers decided to strike. They convinced the workers of the neighbouring Belgian-owned linen 
factory to join them and then turned their attention to the workers of one more linen factory owned by the Zotov brothers. However, this latter company worked for the Ministry of War and was carefully controlled by the authorities. So, instead of solidary peers, the strikers were met by a police squad. The clash with the police resulted in the violent death of several strikers and the imprisonment of the organisers. ${ }^{50}$

A similar tragedy happened in Ivanovo-Voznesensk, another centre of the textile industry in Russia, some 100 kilometres south from Kostroma. A bloody clash between strikers and police forces left several killed and many wounded. ${ }^{51}$ These brutal repressions caused enormous public outrage. Seven days after the Kostroma conflict, many Russian cities, including Saint Petersburg and Moscow, hosted mass strikes of solidarity. Thus, by applying brutal repression against strikers, the authorities often ended up with the opposite result: these repressions catalysed a new wave of protests.

Workers' solidarity was a serious constraining factor against the temptation to resolve all conflicts by force. The calculation presented in Table 2.1 shows that the percentage of strikes with the intervention of the police or military troops (14 per cent) is higher than the proportion of those strikes, which resulted in arrests (12 per cent), lockouts ( 11 per cent), or banishments ( 3 per cent). These numbers indicate that the appearance of the police and military troops did not necessarily lead to further repressive actions; sometimes it was enough in itself to convince the strikers to terminate their activity and to get back to work.

Table 2.1 demonstrates that lockouts or the dismissal of some workers were an instrument applied by industrialists at least since the mid-1890s. Employers relied on lockouts not only during the strikes but also as preventive measures, to get rid of pro-socialist workers. ${ }^{52}$ During the periods of wars (the Russo-Japanese War in 1904 and 1905 and the First World War) industrialists were less keen to lock down their enterprises in case of labour conflicts. For example, in the second half of 1914, 8.5 per cent of conflicts ended up with lockouts and partial dismissal, but this number decreased to 5.1 in 1915 and 4.9 per cent in $1916 .{ }^{53}$ During wartime, the industrialists could not afford to apply lockout because it meant that the factories ceased to operate, which could disrupt the supplies expected by the Ministry of War or the Ministry of the Navy.

Table 2.1 presents the statistics of those repressive practices that are quantifiable. However, there were practices, such as blacklisting and the cartelisation of the labour market, about which we have only anecdotal evidence. Numerous sources indicate that industrialists had practised blacklisting since, at least, from the early 1890s. Workers, whose names were in the blacklists, had difficulties in finding a job. Kliment Voroshilov, a worker in the early 1900s and later, during the Stalin era, a prominent Soviet politician, recalls in his memoirs how he struggled to find a job after being blacklisted. He was fired from a metallurgy plant in Alchevsk, a company town in the Donbas region (now Eastern Ukraine), and moved some 350 kilometres west. He hoped to find another job in one of the numerous metallurgical or metalworking enterprises of Ekaterinoslav, a large industrial city. However, Voroshilov quickly found out that he cannot get any 
job there either because his name was blacklisted. An informed colleague told Voroshilov that he was probably added to a list by a policeman from Alchevsk, who suspected that Voroshilov had been one of the organisers of a strike there some time ago. Voroshilov's only hope was to find temporary work at a workshop which was not covered by the blacklisting network. ${ }^{54}$

In the case of Voroshilov, the list was probably maintained by the police network. However, evidence indicates that the enterprises also created and distributed blacklists among themselves. ${ }^{55}$ The practice remained popular until the collapse of the Russian Empire, especially in the industrial areas and among large employers. ${ }^{56}$

Industrialists cooperated to protect their interests in the labour market also by signing cartel agreements about the maximum wage limits. ${ }^{57}$ Nikita Khrushchev, a Soviet political leader in the 1950s to the 1960s, recalled in his memoirs the practices of cartels in the labour market of the Donbas around 1908. Some groups of miners approached the owner of a mine demanding to increase their wages and threatening to strike in case their request was rejected. The answer of the owner was the following:

I would gladly give you an increase in pay, but the mine owners have an agreement. It says that we should not have differences in wage rates. So, if all the owners of mines where there are strikes going on increase their wages, I will do the same for you. If they do not, then I am sorry, but I will not increase your wages either.

Khrushchev pointed out that when other strikers got their raises, the owner of their mine "made good on his word and increased wages, but only for men with families; the single men did not get raises". ${ }^{58}$

\section{The outcome of the strikes}

How did the repressive practices affect the outcome of the strikes? Table 2.2 presents the rate of successful strikes and how this relates to specific repressive practices. These data indicate that the application of repressive forces did not always mean that the workers' requirements were not satisfied. Moreover, the share of fully or partially satisfied demands is even higher in those cases when the police were involved, and various repressive means were applied compared to the overall number of the strikes.

A possible explanation might be that police and military forces were usually sent to handle those cases, which were especially difficult, threatening to outburst in mass violence (or already doing so). Such cases came under the close control of the authorities who often detected that the workers' rights had been violated.

Second, the government sent more often the police and military forces to large enterprises than to the small ones. The demands of the strikers on large factories were usually more diverse compared to those in small enterprises. Thus, the administrations of large factories had more opportunities to negotiate and to 
Table 2.2 Share of the strikes resulting in total or partial satisfaction of the strikers' demands, including those which were accompanied by some repressive practices

\begin{tabular}{lllllll}
\hline Year & All & $\begin{array}{l}\text { Police or } \\
\text { military } \\
\text { intervention }\end{array}$ & Trials & Arrests & Banishment & $\begin{array}{l}\text { Lockout or } \\
\text { dismissal of a } \\
\text { group of workers }\end{array}$ \\
\hline 1895 & $22 \%$ & $40 \%$ & $39 \%$ & $21 \%$ & $50 \%$ & $\mathrm{n} / \mathrm{a}$ \\
1896 & $33 \%$ & $51 \%$ & $25 \%$ & $39 \%$ & $33 \%$ & $60 \%$ \\
1897 & $31 \%$ & $46 \%$ & $56 \%$ & $37 \%$ & $36 \%$ & $33 \%$ \\
1898 & $29 \%$ & $42 \%$ & $29 \%$ & $31 \%$ & $33 \%$ & $38 \%$ \\
1899 & $19 \%$ & $29 \%$ & $27 \%$ & $22 \%$ & $27 \%$ & $40 \%$ \\
1900 & $18 \%$ & $28 \%$ & $50 \%$ & $13 \%$ & $10 \%$ & $33 \%$ \\
1901 & $16 \%$ & $39 \%$ & $40 \%$ & $21 \%$ & $33 \%$ & $100 \%$ \\
1902 & $12 \%$ & $26 \%$ & $33 \%$ & $16 \%$ & $33 \%$ & $20 \%$ \\
1903 & $13 \%$ & $37 \%$ & $29 \%$ & $31 \%$ & $17 \%$ & $33 \%$ \\
1904 & $13 \%$ & $26 \%$ & $\mathrm{n} / \mathrm{a}$ & $38 \%$ & $43 \%$ & $36 \%$ \\
AVG & $20 \%$ & $36 \%$ & $36 \%$ & $27 \%$ & $32 \%$ & $44 \%$ \\
\hline
\end{tabular}

satisfy at least a part of the demands. The main reason to strike was the workers' dissatisfaction with their wages. Around half (in some years, more than 65 per cent ${ }^{59}$ of all strikes in Russia happened because of wage-related conflicts. However, the diversity of demands corresponded to the size of the enterprises. Large enterprises usually attracted many qualified workers who expected a certain level of working and living conditions. The larger an enterprise was, the more resources it had to invest in social infrastructure and to satisfy such needs. Consequently, though strikes at large enterprises were the most probable to attract repressive police intervention, still, these were the employers who were also the most open for negotiations to satisfy the workers' requests.

Industrialists were relatively open towards the workers' demands in the presence of police and military forces also because they were afraid of provoking a violent collision between strikers and the police. The arrests of strike organisers following the appearance of police often led to mass labour violence, which resulted in damaging factory property, stopping production and ultimately in financial loss.

Local state representatives also had an impact on the outcome of the strikes. In 15 per cent of conflicts, the factory inspection or another representative of the local authorities (a governor or a persecutor) interfered with the conflict and tried to resolve it. Statistics indicate that these actions tended to produce positive results: the chance to come to a compromise between the conflicting sides was higher in the presence of a state representative. However, if the state representative was inactive or aggressive with the strikers, his behaviour could provoke the explosion of violence. The strike of miners in the Central mine of Iuzovka in October 1898 was such a case. The labour conflict was peaceful until a mining engineer called Sutulov decided to intrude. The crowd of striking miners was standing around the pit head when Sutulov appeared in a state of inebriation and asked why the workers were not starting their shift. He also began to push them towards the entrance 
of the crate. A voice from the crowd shouted that they wanted a raise in pay. Then one of the strikers stepped forward and tried to formulate the workers' grievances. However, Sutulov interrupted the worker and ordered the foreman to take the man's name and have him fired. At that point, the entire crowd began to demand that they all be fired and hissed at Sutulov. After that, some 150 miners headed to the nearby ironworks, forced metallurgists to cease their work and knocked out all the windows in the workshop. ${ }^{60}$

Overall, several factors affected the outcome of a strike, including the actions of police, factory inspectors and local authorities, the behaviour of the strikers, the flexibility of the management, the efficiency of communication channels between the management and the strikers and the level of the activities of revolutionary organisations.

\section{Conclusions}

Strikes and unions were unlawful in the Russian Empire until 1905, and those who dared to participate in strikes were punished. Criminal punishment was combined with administrative measures. However, often it was the only way to attract attention to the workers' problems.

The government and the industrialists looked at strikes as a deviation from the norm and disturbance of the public order. They considered any compromise with strikers as weakness and inspiration for other workers to fight for their demands. Therefore, they gave preference to repression over negotiations. Moreover, the hierarchical relationship between the main stakeholders made the idea of strikes unacceptable. Some representatives of the state and some entrepreneurs started to change their attitude gradually to strikes and workers' organisations only from the early twentieth century. They advocated for relaxing labour law and, at the same time, for an increase in spending on welfare work.

To repress the labour movement, the government and the industrialists spent a significant amount of resources on repressive forces, including factory police and the employment of Cossacks. As preventive measurements, the police established a system of surveillance and spying. The secret political police were continuously searching for agitators among workers.

Employers did not have enough power to repress the labour movement and, at the same time, did not bother to establish efficient communication channels with their workers. The total ban of worker organisations which would be able to formulate and communicate the employees' demands, radicalised the labour movement and pushed the workers into the arms of revolutionaries. Any extreme violence to repress labour movement often had the opposite effect: it motivated the workers to increase solidarity and led to the outburst of mass-scale public protests.

The gradual improvement of working and living conditions from the late $1880 \mathrm{~s}$ did not eliminate the labour movement: workers went to strikes relatively often, especially in the period from 1905 to 1907 . In the period from 1895 to 1905 , the government's reaction to the strikes was relatively harsh; repression peaked in 
1905. Still, the labour movement during the Russian Revolution of 1905 became so overpowering that it was obviously no longer possible to repress it with police and military forces; the government had to relax the labour legislation.

When the labour movement started to decline from 1906, the authorities again returned to the old repressive methods persecuting both legal and informal worker organisations. They were able to handle local conflicts; however, they failed to confront the labour movement on a large scale. Although the labour movement was relatively weak in the period from 1907 to 1911, it sharply intensified from 1912 and in five years. The labour movement emerging as a mass phenomenon in the Russian Empire in the late nineteenth century and strengthening due to the confrontation with the authorities played an imperative role in the Revolution of 1917 and the collapse of the tsarism.

\section{Acknowledgements}

The authors thank Dóra Mérai and the editors for their comments on the draft of this chapter.

\section{Notes}

1 Zinaida I. Peregudova, Politicheskii sysk Rossii: 1880-1917 (Moscow: ROSSPEN, 2000), 200.

2 E.g. Nikolai N. Polianskii, Stachki rabochikh i ugolovnyi zakon (St. Petersburg: tip. t-va Obshchestv. pol'za, 1907); Ivan Kh. Ozerov, Politika po rabochemu voprosu v Rossii za poslednie gody: (Po neizd. dokumentam) (Moscow: T-vo I. D. Sytina, 1906); Lev A. Tikhomirov, Rabochii vopros (prakticheskie sposoby ego resheniia) (Moscow: Tip. V. A. Zhdanovich, 1909).

3 See more in Evgeniia A. Vorontsova, Predprinimatel 'skie organizatsii v Rossii: istoriografiia, istochniki, istoriia (Moscow: Eterna, 2013), 31 and further.

4 E.g. Andrei F. Vovchik, Politika tsarizma po rabochemu voprosu v predrevoliutsionnyi period (1895-1904) (Lvov: Izd-vo L'vov. un-ta, 1964); Vladimir Ia. Laverychev, Tsarizm i rabochii vopros v Rossii (1861-1917 gg.) (Moscow: Mysl', 1972); Iurii I. Kir'ianov, Sotsial'no-politicheskii protest rabochikh Rossii v gody Pervoi mirovoi voiny, iiul' 1914 - fevral' $1917 \mathrm{gg}$. (Moscow: In-t rossiiskoi istorii RAN, 2005).

5 E.g. Jacob Walkin, "The Attitude of the Tsarist Government Toward the Labour Problem," American Slavic and East European Review 13, no. 2 (1954); Gaston V. Rimlinger, "The Management of Labour Protest in Tsarist Russia: 1870-1905," International Review of Social History 5, no. 2 (1960); Theodore H. Von Laue, "Tsarist Labour Policy, 1895-1903," The Journal of Modern History 34, no. 2 (1962). These were followed by case studies on the repression of striking workers during specific conflicts, such as the Kreenholm strike in 1872, the Iuzovka cholera riot in 1892 and the Lena Goldfield massacre in 1912. See Reginald E. Zelnik, Law and Disorder on the Narova River: The Kreenholm Strike of 1872 (Berkeley, CA: University of California Press, 1995); Theodore H. Friedgut, "Labour Violence and Regime Brutality in tsarist Russia: The Iuzovka Cholera Riots of 1892," Slavic Review 46, no. 2 (1987); Michael Melancon, The Lena Goldfields Massacre and the Crisis of the Late Tsarist State (College Station: Texas A\&M University Press, 2006). While Soviet historians focused on the pieces of evidence about the cooperation between the industrialists and the government, Western scholars pointed out the controversial character of the tsarist labour policy and the conflicting interests of not only the industrialists and the government but 
also within the government, between the various departments. Both Soviet scholars and their Western counterparts approached the topic from the political angle, i.e. its failure to advent the Revolution of 1917. Another limitation of these studies was that they were based on anecdotal evidence and drew their conclusions from a set of selected data.

6 Irina M. Pushkareva, Valerii I. Bovykin, and V. P. Zheltova, Rabochee dvizhenie v Rossii. 1895 -fevral' 1917 g. Khronika. Vyp. 1-10 (Moscow: St. Petersburg, 1992-2008).

7 More about the project: Leonid I. Borodkin, Irina M. Pushkareva, and Irina V. Shilnikova, "The Structure and Dynamics of the Workers' Protest Movement at the Beginning of the 20th Century in Russia: Database Analysis," in Striking Numbers. New Approaches to Strike Research (Amsterdam: IISH, 2012), 74-76.

8 Irina M. Pushkareva et al., Trudovye konflikty i rabochee dvizhenie v Rossii na rubezhe $X I X-X X$ vekov (St. Peretsburg: Aleteiia, 2011); Borodkin, Pushkareva, and Shilnikova, "The Structure and Dynamics of the Workers' Protest Movement at the Beginning of the 20th Century in Russia: Database Analysis"; Irina V. Shil'nikova, Trudovye konflikty v promyshlennosti dorevoliutsionnoi Rossii: ot statistiki k mikroanalizu (Moscow: MAKS Press, 2014).

9 Daniel R. Brower, "Labour Violence in Russia in the Late Nineteenth Century," Slavic Review 41, no. 3 (1982): 421.

10 Kir'ianov, Sotsial'no-politicheskii protest rabochikh Rossii v gody Pervoi mirovoi voiny, iiul'1914 - fevral'1917 gg., 41.

11 Sources: Pushkareva, Bovykin, and Zheltova, Rabochee dvizhenie v Rossii. 1895 fevral' 1917 g. Khronika. Vyp. 1-10; S. S. Atapin, Khronika rabochego dvizheniia v Rossii s 3 iiunia 1907 g. po 31 dekabria 1910 g. (Moscow: In-t istorii SSSR, 1981); Ministerstvo Finansov, Svod otchetov fabrichnykh inspektorov za 1911 god (St. Petersburg: Tip. V. F. Kirshbauma, 1912), 291; Ministerstvo Finansov, Svod otchetov fabrichnykh inspektorov za 1912 god (St. Petersburg: Tip. V. F. Kirshbauma, 1913), 293; Ministerstvo Finansov, Svod otchetov fabrichnykh inspektorov za 1913 god (Petrograd: Tip. V. F. Kirshbauma, 1914), 270; Georgii G. Kasarov, Stachechnoe dvizhenie v Rossii v gody Pervoi mirovoi voiny. Iiul'1914 g. -fevral' 1917 g.: Khronika (St. Petersburg: Nestor-Istoriia, 2019), 748-49.

12 Walkin, "The Attitude of the Tsarist Government Toward the Labour Problem," 165.

13 Pushkareva et al., Trudovye konflikty i rabochee dvizhenie v Rossii na rubezhe XIX$X X$ vekov, 115 and further.

14 Polianskii, Stachki rabochikh i ugolovnyi zakon, 380.

15 Ibid.

16 Ministerstvo Finansov, Svod otchetov fabrichnykh inspektorov za 1905 g. (St. Petersburg: Tip. V. F. Kirshbauma, 1908), XVI.

17 Stephen A. Smith, Red Petrograd: Revolution in the factories, 1917-1918 (Cambridge: Cambridge University Press, 1985), 38.

18 Polianskii, Stachki rabochikh i ugolovnyi zakon, 365.

19 Rimlinger, "The Management of Labour Protest in Tsarist Russia: 1870-1905," 235.

20 Sergei R. Glazunov, "Fabrichnoe zakonodatel'stvo i mekhanizmy ego realizatsii. 18821914 gg," Ekonomicheskaia istoriia 14, no. 2 (2018): 340.

21 Ivan L. Goremykin, Sekretnyi tsirkuliar ministra vnutrennikh del ot 12 avgusta 1897 goda [o bor'be s revoliutsionnym dvizheniem sredi rabochikh] (St. Petersburg: Gruppa rabochikh revoliutsionerov, 1897).

22 The "economic" strikes (i.e. wage and working day related) were decriminalised in 1905. In practice the authorities often categorised such strikes as "political" if they were accompanied by tensions with the police (including verbal abuse). Strikes covering workers of several enterprises were another exception. The authorities suspected that such strikes were coordinated by socialist organisations and therefore considered them as "political", i.e. unlawful.

23 Victoria E. Bonnell, "Radical Politics and Organized Labour in Pre-Revolutionary Moscow, 1905-1914," Journal of Social History 12, no. 2 (1978): 288. 
24 Nikolai S. Avdakov, "O merakh k obespecheniiu gornykh promyslov rabochimi rukami i ob uregulirovanii prodazhi vodki v raione gornykh promyslov," in Trudy XVIII s"ezda gornopromyshlennikov Iuga Rossii (Kharkov: Tip. Zil'bel'berga, 1894), 356-57.

25 Leonid I. Borodkin et al., "Ne rublem edinym»: Trudovye stimuly rabochikhtekstil'shchikov dorevoliutsionnoi Rossii (Moscow: ROSSPEN, 2010).

26 Volodymyr Kulikov, Pidpryjemstva j suspil'stvo $v$ zavods'kyh $i$ shahtars'kyh poselennjah Donbasu ta Prydniprov'ja v 1870-1917 rr. (Kharkiv: Vyd-vo Harkivs'kogo universytetu, 2019); Volodymyr Kulikov, "Necessity or Luxury? Welfare Work in the Company Towns of the Russian Empire," Jahrbuch für Wirtschaftsgeschichte/ Economic History Yearbook 60, no. 2 (2019).

27 Ignatii I. Iasiukovich, Zapiska po rabochemu voprosu v Rossii (St. Petersburg, 1905), 3.

28 Vladimir Ia. Laverychev, "Antirabochie soiuzy kapitalistov v 1917 godu," Vestnik Moskovskogo universiteta. Seriia 9. Istoriia, no. 5 (1960).

29 Laverychev, Tsarizm i rabochii vopros v Rossii (1861-1917 gg.).

30 Vladimir I. Shtein, Zubatovshchina: Stranichka iz istorii rabochego voprosa $v$ Rossii (Moscow: tip. t-va I. D. Sytina, 1913), 103.

31 Susan P. McCaffray, "Origins of Labour Policy in the Russian Coal and Steel Industry, 1874-1900," The Journal of Economic History 47, no. 4 (1987): 951.

32 S"ezd gornopromyshlennikov Iuga Rossii, Trudy XVIII S"ezda gornopromyshlennikov Iuga Rossii, byvshego v g. Khar'kove s 1 po 14 dekabria 1893 goda. Otchety, protokoly i doklady (Kharov: Tip. Zil'bel'berga, 1894), 334.

33 Walkin, "The Attitude of the Tsarist Government Toward the Labour Problem," 177-78.

34 Edward H. Judge, Plehve: Repression and Reform in Imperial Russia, 1902-1904 (Syracuse: Syracuse University Press, 1983), 126.

35 For example during the first labour conflict in Iuzovka in 1874, the company organised a group of some 40 skilled workers (probably many of British nationality) who dispersed the crowd of striking miners and beat up some of them. They did the same in 1887: armed a group of skilled metallurgists who imprisoned some 50 individuals among striking miners and later handed them to the police representatives. During this conflict, three strikers were killed, and 15 were wounded. Source: State Archive of the Russian Federation, Moscow. F. 7952. Op. 6. Doc. 119. P. 6, 10-11, 46.

36 Lev A. Liberman, V strane chernogo zolota: Ocherk razvitiia zarabotnoi platy i revoliutsionnogo dvizheniia gornorabochikh Donbassa (Moscow and Leningrad: Gos. izd-vo, 1926), 62-63; Theodore H. Friedgut, Iuzovka and Revolution, Vol. I: Life and Work in Russia's Donbass, 1869-1924 (Princeton, NJ: Princeton University Press, 1994), 207.

37 Polianskii, Stachki rabochikh i ugolovnyi zakon, 368.

38 Ozerov, Politika po rabochemu voprosu v Rossii za poslednie gody: (Po neizd. dokumentam), 160.

39 Ibid., 98.

40 Judge, Plehve: Repression and Reform in Imperial Russia, 1902-1904, 130.

41 Peregudova, Politicheskii sysk Rossii: 1880-1917, 193.

42 State Archive of the Russian Federation, Moscow. F. 7952. Op. 6. Doc. 120. P. 31.

43 Judge, Plehve: Repression and Reform in Imperial Russia, 1902-1904, 142.

44 Shtein, Zubatovshchina: Stranichka iz istorii rabochego voprosa v Rossii, 146.

45 Judge, Plehve: Repression and Reform in Imperial Russia, 1902-1904, 142.

46 Ozerov, Politika po rabochemu voprosu v Rossii za poslednie gody: (Po neizd. dokumentam), 157; Laverychev, Tsarizm i rabochii vopros v Rossii (1861-1917 gg.), 120.

47 Judge, Plehve: Repression and Reform in Imperial Russia, 1902-1904, 127.

48 About the database and its sources see Borodkin, Pushkareva and Shilnikova, "The structure and dynamics of the workers' protest movement at the beginning of the 20th century in Russia: Database analysis".

49 Michael Melancon, "The Ninth Circle: The Lena goldfield workers and the massacre of 4 April 1912," Slavic Review 53, no. 3 (1994): 793-95. 
50 State Archive of the Russian Federation, Moscow. F. DP 4 d-vo. 1915. Doc. 30. Part 2. P. 12-12back, 15.

51 Vladimir Ia. Laverychev, Rabochee dvizhenie v Ivanovo-Voznesenske v gody pervoi mirovoi voiny (1914 - fevral' 1917 gg.) (Moscow: Izd-vo Mosk. un-ta, 1957), 112-17.

52 Irina M. Pushkareva, Rabochee dvizhenie v Rossii v period reaktsii, 1907-1910 gg. (Moscow: Nauka, 1989), 54.

53 Calculated based on: Kasarov, Stachechnoe dvizhenie v Rossii v gody Pervoi mirovoi voiny. Iiul' 1914 g. - fevral'1917 g.: Khronika.

54 Kliment E. Voroshilov, Rasskazy o zhizni (Vospominaniia). Kniga pervaia (Moscow: Politizdat, 1968), 103.

55 Ozerov, Politika po rabochemu voprosu v Rossii za poslednie gody: (Po neizd. dokumentam), 92-93.

56 Pushkareva, Rabochee dvizhenie v Rossii v period reaktsii, 1907-1910 gg., 25.

57 For examples, see Ozerov, Politika po rabochemu voprosu v Rossii za poslednie gody: (Po neizd. dokumentam), 92; Pushkareva, Rabochee dvizhenie v Rossii v period reaktsii, 1907-1910 gg., 39.

58 Nikita S. Khrushchev, Khrushchev Remembers. The Glasnost Tapes (Boston, MA: Little Brown \& Co, 1990), 7-9.

59 Calculated based on Kasarov, Stachechnoe dvizhenie v Rossii v gody Pervoi mirovoi voiny. Iiul' 1914 g. - fevral' 1917 g.: Khronika.

60 State Archive of the Russian Federation, Moscow. F. 7952. Op. 6. Doc. 1. P. 60. 